\title{
Exploring the Link between Corporate Governance Characteristics and Effective Corporate Tax Rate: A Panel Data Approach on U.S. Listed Companies
}

\author{
Radu Alin Păunescu, Georgeta Vintilă and Ştefan Cristian Gherghina \\ Department of Finance, Bucharest University of Economic Studies, Bucharest, Romania
}

Correspondence should be addressed to: Radu Alin Păunescu; radupaunescu696@gmail.com

Received date: 12 February 2016; Accepted date: 6 Juin 2016; Published date: 5 October 2016

Academic Editor: Aura Emanuela Domil

Copyright (C) 2016. Radu Alin Păunescu, Georgeta Vintilă and Ştefan Cristian Gherghina . Distributed under Creative Commons CC-BY 4.0

\begin{abstract}
We blend the corporate governance and corporate taxation literature streams to study the association between board, abreast CEO characteristics, and effective corporate tax rate. We have tried to sweep a broad brush over a large number of different econometric techniques that are relevant to the analysis of financial data. Using a sample of 50 companies, mainly from the technology area, listed at NASDAQ and component of Dow Jones index, over the period 20002013, the empirical approach employs panel least squares and quantile regressions, as well as robustness checks by means of estimated generalized least squares, generalized linear model, and generalized method of moments. We find that board independence and board size have a statistically significant negative impact on effective corporate tax rate. It is also important to note that board independence Granger cause corporate taxation. Regardless of its robustness, CEO ownership reveals a mixed influence: positive for quantiles between 0.3-0.5 and negative at the 0.9 quantile. We also find a mixed relationship between CEO tenure and corporate taxtion.
\end{abstract}

Keywords: effective corporate tax rate; corporate governance characteristics; panel data regression models; quantile regression.

Cite this Article as: Radu Alin Păunescu, Georgeta Vintilă and Ştefan Cristian Gherghina (2016)," Exploring the Link between Corporate Governance Characteristics and Effective Corporate Tax Rate: A Panel Data Approach on U.S. Listed Companies", Journal of Financial Studies \& Research, Vol. 2016 (2016), Article ID 857506, DOI: $10.5171 / 2016.857506$ 


\section{Introduction}

A special subject of finance is the corporate finance being not only comprehensive in terms of information presented, but also of interest to a broad range of stakeholders in the financial markets: shareholders, managers, investors. In the academic literature about corporate finance, numerous studies are devoted to the development of forecasting techniques for markets evolution, but there are also authors that make reference to corporate governance, an area for which has been granted a growing interest after the crisis of 2007. Besides specific phenomena from the world of finance, the human nature is an important element that leaves its mark (seemingly invisible, but significant) on financial markets. And the better we can support this referring to the notorious studies made by Kahneman and Tversky $(1979,1986)$. In this paper, we tried to apply a procedure seen in watercolor paintings where was desired to obtain a gradient between two colors, so we applied the 'brush' of the empirical research on both corporate governance and the effective corporate tax rate. The novelty brought consists of an interdisciplinary study, dual, which includes a representation of fiscal management and the board characteristics, focusing on the idea of human nature as an influence factor, and we have highlighted the interdependencies between the two areas, all in the context of corporate finance. Although the literature about these two combined topics is rare, the ultimate goal of this paper seeks to identify whether corporate governance influences the effective corporate tax rate, starting from the premise that earlier studies showed that separate, the two influence the financial performance (see Lee and Swenson, 2012; MacAvoy and Millstein, 1999).

The effective tax rate can be used in financial analysis with duties that transcend the sphere of fiscal management, from researching the lack of protection for minority shareholders to the means of tax avoidance, legal or not, used for the process of tax optimization. Perhaps even more important than corporate governance, the effective tax rate is a useful tool dedicated to the stakeholders 'trinity' and to the analysis of human relationships within it, translated into financial decisions targeting the company. Another goal is to identify correlations or connections between effective tax rate and corporate governance both in terms of objective point of view and subjective one (human nature) that can be considered as references for future papers on this issue. It is interesting to see if and how the management decisions (CEO, Board of Directors) on reducing the effective rate are influenced by rules imposed by corporate governance, and whether they may affect the company as a whole. Erkens et al. (2012) obtained results showing that corporate governance has affected financial performance during the crisis in 2007, meaning that companies with a large number of independent members have urged the shareholders to bring more capital and took fewer risky decisions, but that would had been favorable for company.

The paper proceeds as follows. Section 2 presents the prior literature. The data and empirical setting are provided in Section 3. Empirical results follow in Section 4. The paper concludes in Section 5 with a summary of the findings.

\section{Prior Research}

Few authors researched the link between corporate governance and effective corporate tax rate. For the convenience of the reader, we named the effective corporate tax rate with the acronym ECTR. At first glance, the effective tax rate leads to the idea of taxes imposed by the state. However, the ECTR is very important in the context of fiscal management and tax optimization, being a good reflection of managerial decisions for the entire company. The literature on the ECTR is abundant and prolific but stands out the works carried out by Devereux and Griffith (1999) being a landmark for this area. Important contributions were made by 
Gupta and Newberry (1997), Richardson and Lanis (2007), along with Nicodème et al. (2014) who studied the relationship between ECTR and financial performance for US companies. They have demonstrated empirically that company size, indebtedness, leverage, ROA, ROE, and other financial items are factors which significantly influence the effective tax rate. Because these results are highly debated in the literature, we gave them a greater attention in the empirical research section. In terms of corporate governance, notable studies on the link between financial performance and characteristics of the Board of Directors (independence, size) and the CEO were brought by Yermack (1996), Metrick and Ishii (2002), Bhagat and Bolton (2008)

Studies that explicitly include both elements of corporate governance and ECTR are very few, but some authors have attempted an analysis between the governance and tax avoidance methods, making an indirect link between the two. Sometimes confused with tax aggressiveness, Watson (2011) defined the legal tax avoidance as all means and strategies taken by the company, through the manager and the Board of Directors to reduce the tax burden, in other words, to reduce the effective corporate tax rate. Bauman and Schadewald (2001) showed that shareholders have appreciated the managers who had the ability to reduce the ECTR and have paid them according to the level of tax burden reduction. Armstrong et al. (2015) considered that unless paying more attention to agent problems that occur within a company, managers will apply more methods of tax avoidance to reduce the ECTR and to show a positive image to shareholders, but sometimes these methods may have negative effects on company's performance.

Although the tax planning is significant from a financial point of view, a manager should not permit the 'tax' tail wag the financial 'dog'. Hanlon and Heitzman (2010), as well as Gallemore et al. (2012) consider companies that use a small level of tax avoidance to reduce ECTR, as marked by dilemma 'under- sheltering puzzle'. As there is no clear evidence to support that tax avoidance involves direct costs, Gallemore et al. (2012) do not understand why some companies do not use this method. On the other hand, a CEO knows that all financial decisions have tax consequences and he should not be afraid to take a decision only from this perspective. Desai and Dharmapala (2006) argue that by reducing tax avoidance, as part of the tax planning, shareholders can control and reduce managerial deviations resulting from the agent's problem. The purpose of tax planning is to identify all the solutions that streamline the company's financial situation by reducing tax obligations. Desai and Dharmapala (2006) suppose that if by reducing the ECTR, using the methods of tax avoidance, the transparency of the company is affected, then there is an increase in the opportunities for CEOs to use the company's financial resources in its own interest, and appears the phenomenon named by literature 'managerial rent extraction'. Also, Desai and Dharmapala (2006) state that this is not possible in companies showing good corporate governance and obtained empirical results that support a negative relation between the CEO's remuneration in the form of equity ('manager's equity incentives') and tax avoidance/reduction of ECTR. Armstrong et al. (2015) challenged this idea and considered this type of CEO's remuneration as part of corporate governance mechanism, rewarding being determined by the Board of Directors in order to ease the agent problems. Thus, compensation in the form of equity should be functional in companies with lower corporate governance (small number of independent members, others). Further, Vintilă and Păunescu (2015) provide empirical evidence for large NASDAQ listed companies, components of Dow Jones, showing that compensation as bonuses has a positive relationship with ECTR. Rego and Wilson (2012) acquired empirical evidence that the ECTR reduction through tax avoidance is correlated with high levels of CEO compensation. 
Dyreng et al. (2010) presented evidence that CEO predisposition towards reducing the effective tax rate by using aggressive tax avoidance is preserved even if they are employed at the same position in another firm. Thus, the ECTR becomes an important milestone when companies and boards of directors, interested in tax planning, analyze managerial skills of a candidate for CEO position. Blaylock (2011) analyzed a large panel of US firms, but was unable to reveal any strong evidence of a link between tax avoidance and rent extraction among poorly governed firms. Consequently, the empirical undertaking failed to support the theory that U.S. companies' managers practice tax avoidance schemes to ease rent extraction from shareholders. Florackis (2008) pointed out that executive ownership lessens discretionary spending, and, thereupon, the agency conflicts between managers and shareholders.

Studying the relationship between effective tax rate and corporate governance, Armstrong et al. (2015) proposed the quantile regression $(\mathrm{QR})$ estimation method instead of the consecrated OLS econometric method that is conditioned mean type. The QR estimation follows the relationship between corporate governance and the entire distribution of ECTR because the level of tax avoidance influences the latter. Tax avoidance was seen as a riskier opportunity available to the management. Hence, a bigger Board of Directors and more efficient will realize the benefits of cash flows by reducing the effective tax rate and will want to increase tax avoidance because it does not bear a risk in terms of investment. Awareness of board members is relevant, for they must know when is exceeded the legal and moral limit to reduce the ECTR, because too much use of tax avoidance may have costs that exceed the tax savings achieved through reduced taxation. Armstrong et al. (2015) have included the independence and the financial expertise of the members of the Board in analyzing the relationship ECTR/corporate governance, and noted that there is a positive link between independence, financial expertise, and tax avoidance on the left side of the tax avoidance distribution and a negative relation to the right side. Thus it was shown that a company with several independent members and with developed financial expertise may reduce problems of agent arising with tax avoidance (over/under utilized) used by the CEO to reduce the ECTR in an ineffective governance conditions. Robinson et al. (2012) have studied the role of financial development of the company and have shown a positive link between the degree of financial expertise of the audit committee and tax avoidance applied to reduce the ECTR, but found that when companies consider that tax avoidance is risky the link becomes negative.

Minnick and Noga (2010) demonstrated empirically that a Board of Directors that do not show a balance between members (executive and independent) will lead to an increase in the effective tax rate. Florackis (2008) believes that shareholders holding large blocks of shares will benefit from the advantage of reducing the ECTR and will require the manager to fulfill this task but they want to monitor this process. Chen et al. (2010) consider that shareholders will be the most affected by the penalties and reputational costs that exist for the use of tax avoidance, the proof of their existence being that not all companies have low levels of ECTR. Ribeiro et al. (2015) analyzed the determinants of effective tax rate and included elements of corporate governance. They obtained evidence supporting that insider's holdings of shares known as 'insider ownership', are associated with lower levels of ECTR. Another element identified was the concentration of ownership that for low levels was correlated with a higher ECTR. Ribeiro et al. (2015) obtained results showing that companies with a large number of members inside boards of directors had a higher ECTR. The same positive significant relationship was found between the number of independent members and the ECTR. 
Florackis (2008) considers that often managers are not interested in reducing the ECTR, which is positive for shareholders' patrimony, because it does not directly fulfill their interests. Therefore, to be incentivized to reduce ECTR and to work out their duties of increasing the shareholders' wealth, managers should be rewarded in company's shares. Through this mechanism of corporate governance, the interests of both parties in the ECTR reduction become the same and thus, it reduces the information asymmetry and agent issues. Badertscher et al. (2013) believed that through ownership of shares, the manager would not want to reduce too much the ECTR by any means, because it increases the risk of being affected in both positions they hold in the company. Subscribed to this idea were Fraile and Fradejas (2014) who supported the idea that once the manager will hold shares, he will have a greater power to act in his own interest.

Another element of corporate governance to be analyzed in conjunction with the effective tax rate is the structure of the Board and its characteristics. Studying the empirical relationship between the number of members from the board of directors, and financial performance (ROA, ROE, ROIC, Tobin Q), Vintilă et al. (2015) obtained mixed results. Wahab and Holland (2012) consider that these results are due to the experience brought by a large number of members, but also by hindering the adoption of financial decisions of each member. Florackis (2008) considers that a greater number of nonexecutive members have an important role in monitoring information asymmetry related to financial decisions. In addition, Vintilă et al. (2015) obtained results that support this idea.

\section{Research Design}

\section{Sample data}

This study examines 50 companies, mainly from the technology area, listed at NASDAQ and component of Dow Jones index, from 2000 to 2013. The sample of issuers is drawn from Thomson Reuters Eikon database. Variable definitions are presented in

Table 1. We use the effective corporate tax rate as outcome variable, together with characteristics of board (independence and size) and CEO (ownership and tenure) as explanatory variables. 
Table 1: Definitions of variables used in empirical analysis

\begin{tabular}{|l|l|}
\hline Variables & \multicolumn{1}{c|}{ Description } \\
\hline \multicolumn{2}{|c|}{ Variables towards taxation (Dependent variable) } \\
\hline \multicolumn{2}{|c|}{ Variables towards corporate governance characteristics } \\
(Independent variables) \\
\hline Board characteristics
\end{tabular}

Source: Author's own work.

With respect to firm-level variables, we control firm size, performance, and indebtedness. The political cost theory advocates a positive relation between firm size and tax since larger firms register higher degrees of political costs such as public scrutiny. Instead, the political power theory specifies a negative connection for the reason that larger companies show more political power that can be disposed to handle their tax burden or lobby lawmaking in their benefit. Stickney and McGee (1982) and 
Porcano (1986) find a significantly negative link between effective corporate tax rate and firm size, whereas Zimmerman (1983) and Omer et al. (1993) revealed a significantly positive relation. Nevertheless, other studies provide evidence for a lack of association (Jacob, 1996; Gupta and Newberry, 1997; Mills et al., 1998).

Concerning financial performance, Noor et al. (2010) finds that firms with higher return on assets face lower effective corporate tax rates, whereas Gupta and Newberry (1997) ascertain that ETRs are systematically related to return on assets.

As regards indebtedness, Lasfer (1995) uncovers a weak association between leverage and effective tax rates, concluding that companies decide on capital structure to lessen agency costs rather than to benefit from tax deduction. Further, Gupta and Newberry (1997) and Rego and Wilson (2012) establish that firms with high leverage ratios are related with lower effective tax rates harmonious with higher tax avoidance, whereas Wilson (2009) and Lisowsky (2010) proved that tax shelter firms are linked with lower leverage ratios.

\section{Econometric specification}

The data set has the structure of a panel data. Each data point in the panel data indicates the $i$ th firm $(\mathrm{i}=1, \ldots, 50)$ at the $t$ th period $(\mathrm{t}$ $=2000, \ldots, 2013)$. The basic equation model used to explore the link between corporate governance characteristics and effective corporate tax rate is depicted below:

$$
\mathrm{ECTR}_{\mathrm{it}}=\alpha+\beta \mathrm{X}_{\mathrm{it}}+\varepsilon_{\mathrm{it}}
$$

where $E C T R_{i t}$ is ECTR for company $i$ in year $t$, $X_{i t}$ is a set of corporate governance characteristics and firm-level controls, $\varepsilon_{i t}$ is the error term. Primary, we will estimate several panel least squares regressions (both without cross-sectional effects and with cross-section fixed effects). However, 'since traditional OLS and median regression only estimates the relationship at the "center" of the distribution, these techniques cannot detect shifts elsewhere in the distribution of interest' (Armstrong et al., 2015). Consequently, we will employ later on quantile regression technique because it 'is more general and describes changes in both the location and shape of the distribution of interest' (Armstrong et al., 2015). Withal, the robustness of the empirical results will be checked by means of various techniques such as estimated generalized least squares (EGLS), generalized linear model (GLM), and generalized method of moments (GMM).

Furthermore, the Granger (1969) approach is employed in order to examine how much of the current corporate governance characteristics can be explained by past values of them and then to see whether adding lagged values of ECTR can improve the explanation. Corporate governance characteristics are said to be Granger-caused by ECTR if ECTR helps in the prediction of corporate governance characteristics or if the coefficients on the lagged corporate governance characteristics are statistically significant.

\section{Empirical Results}

\section{Summary statistics}

The descriptive statistics of the variables are presented in

Table 2. The mean (median) ECTR for our sample is $28.015 \%(29.30 \%)$. As regards board independence, we acknowledge the 
Table 2: Descriptive statistics

\begin{tabular}{|l|c|c|c|c|c|c|c|c|}
\hline & N & Mean & $\begin{array}{c}\text { Std. } \\
\text { Dev. }\end{array}$ & Min. & $\begin{array}{c}\text { Lower } \\
\text { Quartile }\end{array}$ & Median & $\begin{array}{c}\text { Upper } \\
\text { Quartile }\end{array}$ & Max. \\
\hline ECTR & 70 & 0.28015 & 0.10948 & 0.00000 & 0.22720 & 0.29300 & 0.34900 & 0.82500 \\
\hline BIndep & 70 & 0.12992 & 0.21675 & 0.00000 & 0.00000 & 0.00000 & 0.32258 & 0.66667 \\
\hline BSize & 70 & 2.84301 & 0.37779 & 1.94591 & 2.48491 & 2.89037 & 3.13549 & 3.66356 \\
\hline CEO Hold & 70 & 0.07099 & 0.29439 & 0.00000 & 0.00000 & 0.00000 & 0.02000 & 6.67000 \\
\hline CEO_Tenur & 70 & 2.28571 & 4.63408 & 0.00000 & 0.00000 & 0.00000 & 2.00000 & 26.0000 \\
\hline FSize & 70 & 14.9968 & 4.12562 & 4.17592 & 12.8043 & 16.6818 & 18.2029 & 20.4973 \\
\hline ROA & 70 & 0.09940 & 0.06868 & 0.00086 & 0.05400 & 0.08777 & 0.13528 & 0.65420 \\
\hline Debt/Equit & 70 & 0.73884 & 1.04305 & 0.00000 & 0.05500 & 0.34500 & 0.91500 & 6.62308 \\
\hline Debt/Asset & 70 & 0.45160 & 0.23805 & 0.00000 & 0.27316 & 0.45928 & 0.60044 & 1.21000 \\
\hline
\end{tabular}

Source: Author's computations. For variable description, see

Table 1.

Radu Alin Păunescu, Georgeta Vintilă and Ștefan Cristian Gherghina (2016), Journal of Financial Studies \& 
IBIMA Publishing

Journal of Financial Studies \& Research

http://www.ibimapublishing.com/journals/JFSR/jfsr.html

Vol. 2016 (2016), Article ID 857506, 16 pages

DOI: $10.5171 / 2016.857506$

The selected firms are profitable since the reported mean (median) ROA is $9.940 \%$ $(8.777 \%)$. However, the companies from our sample are highly levered with a mean (median) Debt/Equity ratio of $73.884 \%$ (34.50\%).

Table 3 contains the correlations between the variables. With the exception of the strong uphill (positive) linear relationship between BSize and FSize (0.719553), all of them show low correlation coefficients, so that multicollinearity should not be a concern.

Table 3: Correlation Matrix

\begin{tabular}{|c|c|c|c|c|c|c|c|c|c|}
\hline & (1) & (2) & (3) & (4) & (5) & (6) & (7) & (8) & (9) \\
\hline ECTR (1) & $\begin{array}{c}1 \\
----\end{array}$ & & & & & & & & \\
\hline BIndep (2) & $\begin{array}{c}-0.16923 \\
(-4.53647)\end{array}$ & $\begin{array}{c}1 \\
----\end{array}$ & & & & & & & \\
\hline BSize (3) & $\begin{array}{c}-0.01559 \\
(-0.41187)\end{array}$ & $\begin{array}{l}0.032376 \\
(0.85581)\end{array}$ & 1 & & & & & & \\
\hline CEO_Hold (4) & $\begin{array}{c}-0.04835 \\
(-1.27893)\end{array}$ & $\begin{array}{c}0.133598 \\
(3.561537)\end{array}$ & $\begin{array}{c}-0.17471 \\
(-4.68785)\end{array}$ & $\begin{array}{c}1 \\
----\end{array}$ & & & & & \\
\hline CEO_Tenure (5) & $\begin{array}{c}-0.07464 \\
(-1.97754)\end{array}$ & $\begin{array}{c}0.315052 \\
(8.770205)\end{array}$ & $\begin{array}{c}-0.20716 \\
(-5.59442)\end{array}$ & $\begin{array}{c}0.273982 \\
(7.526535)\end{array}$ & $\begin{array}{c}1 \\
----\end{array}$ & & & & \\
\hline FSize (6) & $\begin{array}{c}0.039469 \\
(1.043576)\end{array}$ & $\begin{array}{c}0.074635 \\
(1.977352)\end{array}$ & $\begin{array}{c}0.719553 \\
(27.37523)\end{array}$ & $\begin{array}{c}-0.22971 \\
(-6.23564)\end{array}$ & $\begin{array}{c}-0.22315 \\
(-6.04815)\end{array}$ & $\begin{array}{c}1 \\
----\end{array}$ & & & \\
\hline ROA (7) & $\begin{array}{c}0.011971 \\
(0.316303)\end{array}$ & $\begin{array}{c}-0.03852 \\
(-1.01856)\end{array}$ & $\begin{array}{c}0.029517 \\
(0.780162)\end{array}$ & $\begin{array}{c}-0.07067 \\
(-1.87179)\end{array}$ & $\begin{array}{c}-0.19029 \\
(-5.12106)\end{array}$ & $\begin{array}{c}0.047459 \\
(1.255271)\end{array}$ & $\begin{array}{c}1 \\
----\end{array}$ & & \\
\hline Debt/Equity (8) & $\begin{array}{l}-0.14022 \\
(-3.7415)\end{array}$ & $\begin{array}{l}0.060176 \\
(1.59272)\end{array}$ & $\begin{array}{c}0.135233 \\
(3.605948)\end{array}$ & $\begin{array}{c}0.043218 \\
(1.142886)\end{array}$ & $\begin{array}{c}0.158724 \\
(4.247294)\end{array}$ & $\begin{array}{c}0.14062 \\
(3.752424)\end{array}$ & $\begin{array}{c}-0.10782 \\
(-\end{array}$ & 1 & \\
\hline Debt/Assets (9) & $\begin{array}{c}0.013419 \\
(0.354562)\end{array}$ & $\begin{array}{c}0.035585 \\
(0.940736)\end{array}$ & $\begin{array}{c}0.528357 \\
(16.44128)\end{array}$ & $\begin{array}{c}-0.12311 \\
(-3.27746)\end{array}$ & $\begin{array}{c}-0.07473 \\
(-1.97983)\end{array}$ & $\begin{array}{c}0.566001 \\
(18.13863)\end{array}$ & $\begin{array}{c}-0.12512 \\
(-\end{array}$ & $\begin{array}{c}0.493554 \\
(14.99289)\end{array}$ & 1 \\
\hline
\end{tabular}

Source: Author's computations. Notes: Figures in parenthesis are t-statistics. For variable description, see

Cite this Article as: Radu Alin Păunescu, Georgeta Vintilă and Ştefan Cristian Gherghina (2016)," Exploring the Link between Corporate Governance Characteristics and Effective Corporate Tax Rate: A Panel Data Approach on U.S. Listed Companies", Journal of Financial Studies \& Research, Vol. 2016 (2016), Article ID 857506, DOI: $10.5171 / 2016.857506$ 
Table 1.

\section{Regression Results}

Table 4 provides the estimates of panel least squares regressions (without cross-sectional effects). We test the influence of board and CEO characteristics on ECTR, both separately and all once. Therefore, board independence
(Eq 1, Eq5, and Eq 7) and board size (Eq 2, Eq 5, and Eq 7) negatively influence ECTR, but the explanatory power of the estimated models is reduced (a mean value of $4.32 \%$ related to R-sq). On the contrary, the relationships between CEO ownership and ECTR (Eq 3, Eq6, and Eq 7), as well as CEO tenure and ECTR (Eq 4, Eq6, and Eq 7), are not statistically significant.

Table 4: Panel least squares regressions of ECTR on corporate governance characteristics and firm-level controls

\begin{tabular}{|c|c|c|c|c|c|c|c|}
\hline & (1) & (2) & (3) & (4) & (5) & (6) & (7) \\
\hline $\mathrm{C}$ & $\begin{array}{c}0.276315^{* * *} \\
(17.5579)\end{array}$ & $\begin{array}{l}0.32893^{* * *} \\
(17.43686)\end{array}$ & $\begin{array}{l}0.273189^{* * *} \\
(16.15389) \\
\end{array}$ & $\begin{array}{l}0.276032^{* * *} \\
(17.36671)\end{array}$ & $\begin{array}{c}\text { 0.338611 }^{* * *} \\
(18.729) \\
\end{array}$ & $\begin{array}{l}0.2777544^{* * *} \\
(17.34884) \\
\end{array}$ & $\begin{array}{l}0.3358566^{* * *} \\
(16.80959)\end{array}$ \\
\hline BIndep & $\begin{array}{c}- \\
0.082644^{* * *}\end{array}$ & & & & $\begin{array}{c}- \\
0.083604^{* * *}\end{array}$ & & $\begin{array}{c}-0.08602^{* * *} \\
(-\end{array}$ \\
\hline BSize & & $\begin{array}{c}- \\
0.031723^{* * *}\end{array}$ & & & $0.033429^{* * *}$ & & $0.033012^{* * *}$ \\
\hline CEO_Hold & & & $\begin{array}{c}-0.010012 \\
(-0.742229)\end{array}$ & & & $\begin{array}{c}-0.007355 \\
(-0.567168)\end{array}$ & $\begin{array}{c}-0.001964 \\
(-0.158066)\end{array}$ \\
\hline CEO_Tenure & & & & $\begin{array}{c}-0.000906 \\
(-1.419475)\end{array}$ & & $\begin{array}{c}-0.000802 \\
(-1.103283) \\
\end{array}$ & $\begin{array}{c}0.000415 \\
(0.615309) \\
\end{array}$ \\
\hline FSize & $\begin{array}{c}0.000628 \\
(0.669348)\end{array}$ & $\begin{array}{c}0.001937 \\
(1.620637)\end{array}$ & $\begin{array}{c}0.0000356 \\
(0.038023)\end{array}$ & $\begin{array}{c}-0.0000141 \\
(-0.015404)\end{array}$ & $\begin{array}{c}0^{0.002482}{ }^{*} \\
(2.165157)\end{array}$ & $\begin{array}{c}-0.0000995 \\
(-0.109937)\end{array}$ & $\begin{array}{c}0.002533^{*} \\
(2.314418)\end{array}$ \\
\hline ROA & $\begin{array}{c}-0.00494 \\
(-0.088551)\end{array}$ & $\begin{array}{c}0.010267 \\
(0.172738) \\
\end{array}$ & $\begin{array}{c}0.003918 \\
(0.065381) \\
\end{array}$ & $\begin{array}{c}-0.003959 \\
(-0.066985) \\
\end{array}$ & $\begin{array}{c}-0.001015 \\
(-0.018179) \\
\end{array}$ & $\begin{array}{c}-0.004602 \\
(-0.0778) \\
\end{array}$ & $\begin{array}{c}0.002866 \\
(0.051643) \\
\end{array}$ \\
\hline Debt/Equity & $\begin{array}{c}- \\
0.018975^{* * *}\end{array}$ & ${ }^{-}{ }^{-}{ }^{-020839^{* * *}}$ & $\begin{array}{c}- \\
0^{-019948}\end{array}$ & $\overline{-}^{-}{ }^{-019363^{* * *}}$ & $\overline{-}^{-}{ }^{0.019613^{* * *}}$ & $\begin{array}{c}- \\
0.019262^{* * *}\end{array}$ & ${ }^{-} \overline{-}^{* 019907^{* *}}$ \\
\hline Debt/Assets & $\begin{array}{l}0.043546^{*} \\
(2.02845)\end{array}$ & $\begin{array}{l}0.059208^{* *} \\
(2.719639)\end{array}$ & $\begin{array}{c}\mathbf{0 . 0 4 7 5 7 8}^{*} \\
(2.175863)\end{array}$ & $\begin{array}{l}0^{0.046721}{ }^{*} \\
(2.142467)\end{array}$ & $\begin{array}{l}0.054945^{*} \\
(2.53306)\end{array}$ & $\begin{array}{c}\mathbf{0 . 0 4 6 3 4 8}^{*} \\
(2.118151)\end{array}$ & $\begin{array}{c}0^{0.055254}{ }^{*} \\
(2.545406)\end{array}$ \\
\hline F-value & $8.109597^{* * *}$ & $4.919170^{* * *}$ & $4.207084^{* * *}$ & $4.298789^{* * *}$ & $7^{2541412} 2^{* * *}$ & $3.620056^{* *}$ & $5.663154^{* * *}$ \\
\hline $\operatorname{Pr}>\mathrm{F}$ & 0.000000 & 0.000197 & 0.000896 & 0.000738 & 0.000000 & 0.001523 & 0.000001 \\
\hline R-sq & 0.055201 & 0.034228 & 0.029419 & 0.030041 & 0.061292 & 0.030390 & 0.061531 \\
\hline Adj R-sq & 0.048394 & 0.027270 & 0.022426 & 0.023053 & 0.053164 & 0.021995 & 0.050665 \\
\hline
\end{tabular}

Source: Author's computations. Notes: ***, **, *, † refer to $0.1 \%, 1 \%, 5 \%$, and $10 \%$ levels of significance, respectively. Figures in parenthesis are t-statistics. Sample: 2000-2013. Periods included: 14. Cross-sections 
included: 50. Total panel (balanced) observations: 700. White cross-section standard errors \& covariance (d.f. corrected). For variable description, see

\section{Table 1.}

Further, the estimates with fixed effects are shown in Table 5. The negative influence of board independence on ECTR is reinforced (Eq 1, Eq5, and Eq 7), but the relationship between board size and ECTR gets out of sight. Nevertheless, we find a negative influence of CEO tenure on ECTR (Eq 4 and Eq 6). This fact is related to the experience of the CEO about tax system, accumulated over the years.

Table 5: Panel least squares regressions (cross-section fixed) of ECTR on corporate governance characteristics and firm-level controls

\begin{tabular}{|c|c|c|c|c|c|c|c|}
\hline & (1) & (2) & (3) & (4) & (5) & (6) & (7) \\
\hline C & $\begin{array}{l}0.532273^{* * *} \\
(7.063226)\end{array}$ & $\begin{array}{l}0.664575^{* * *} \\
(6.227291)\end{array}$ & $\begin{array}{l}\mathbf{0 . 7 2 1 4 9 9}^{* * *} \\
(8.522007)\end{array}$ & $\begin{array}{l}0.621508^{* * *} \\
(6.129386)\end{array}$ & $\begin{array}{l}0.452725^{* * *} \\
(4.337569)\end{array}$ & $\begin{array}{l}0.617492^{* * *} \\
(6.044013)\end{array}$ & $\begin{array}{l}0.428265^{* * *} \\
(3.501418)\end{array}$ \\
\hline BIndep & $\begin{array}{c}- \\
0.064604^{* * *}\end{array}$ & & & & $\begin{array}{c}- \\
0.065754^{* * *}\end{array}$ & & 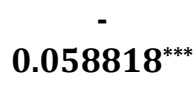 \\
\hline BSize & & $\begin{array}{c}0.029458 \\
(0.95492)\end{array}$ & & & $\begin{array}{c}0.03463 \\
(1.121663)\end{array}$ & & $\begin{array}{c}0.036593 \\
(1.160557)\end{array}$ \\
\hline CEO_Hold & & & $\begin{array}{l}-0.008457 \\
(-1.34537)\end{array}$ & & & $\begin{array}{c}-0.006412 \\
(-1.168939)\end{array}$ & $\begin{array}{c}-0.004468 \\
(-0.771845)\end{array}$ \\
\hline CEO_Tenure & & & & $\begin{array}{c}-0.003941^{*} \\
(-\end{array}$ & & $\begin{array}{c}-0.003873^{*} \\
(-\end{array}$ & $\begin{array}{c}-0.001361 \\
(-0.811394)\end{array}$ \\
\hline FSize & $\begin{array}{c}-0.01491^{* *} \\
(-\end{array}$ & $\begin{array}{c}- \\
0.029949^{* * *}\end{array}$ & $\begin{array}{c}-0.02792^{* * *} \\
(-\end{array}$ & ${ }^{-}-{ }^{-}{ }^{*}$ & $\overline{-}^{-}{ }^{-0.016395^{* * *}}$ & $\begin{array}{c}- \\
0.020295^{* *}\end{array}$ & 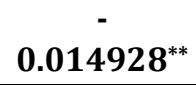 \\
\hline ROA & $\begin{array}{c}0.022793 \\
(0.269671)\end{array}$ & $\begin{array}{c}0.038373 \\
(0.399546)\end{array}$ & $\begin{array}{c}0.024084 \\
(0.257743)\end{array}$ & $\begin{array}{c}0.01015 \\
(0.112225)\end{array}$ & $\begin{array}{c}0.040664 \\
(0.462)\end{array}$ & $\begin{array}{c}0.011073 \\
(0.122965) \\
\end{array}$ & $\begin{array}{c}0.037711 \\
(0.432613)\end{array}$ \\
\hline Debt/Equity & $\begin{array}{c}-0.005272 \\
(-0.530412)\end{array}$ & $\begin{array}{c}-0.003393 \\
(-0.352831) \\
\end{array}$ & $\begin{array}{c}-0.004907 \\
(-0.527184)\end{array}$ & $\begin{array}{c}-0.003945 \\
(-0.409146)\end{array}$ & $\begin{array}{c}-0.003485 \\
(-0.342969)\end{array}$ & $\begin{array}{c}-0.003953 \\
(-0.408995)\end{array}$ & $\begin{array}{c}-0.003003 \\
(-0.293354)\end{array}$ \\
\hline
\end{tabular}

Radu Alin Păunescu, Georgeta Vintilă and Ștefan Cristian Gherghina (2016), Journal of Financial Studies \& Research, DOI: 10.5171/2016.857506 


\begin{tabular}{|c|c|c|c|c|c|c|c|}
\hline Debt/Assets & $\begin{array}{c}-0.040975 \\
(-1.635877)\end{array}$ & $\begin{array}{c}-0.045032^{\dagger} \\
(-\end{array}$ & $\begin{array}{c}-0.046069^{\dagger} \\
(-\end{array}$ & $\begin{array}{c}-0.048219^{\dagger} \\
(-\end{array}$ & $\begin{array}{c}-0.040026 \\
(-1.534826)\end{array}$ & $\begin{array}{c}-0.048406^{\dagger} \\
(-1.94682)\end{array}$ & $\begin{array}{c}-0.041498 \\
(-1.625684)\end{array}$ \\
\hline F-value & $9.174769^{* * *}$ & $8.806047^{* * *}$ & $8.784865^{* * *}$ & $8.919158^{* * *}$ & $9.042934^{* * *}$ & $8.751169^{* * *}$ & $8.716017^{* * *}$ \\
\hline $\operatorname{Pr}>F$ & 0.000000 & 0.000000 & 0.000000 & 0.000000 & 0.000000 & 0.000000 & 0.000000 \\
\hline R-sq & 0.434428 & 0.424378 & 0.423790 & 0.427498 & 0.435762 & 0.427715 & 0.436255 \\
\hline Adj R-sq & 0.387077 & 0.376186 & 0.375549 & 0.379568 & 0.387573 & 0.378840 & 0.386203 \\
\hline
\end{tabular}

Source: Author's computations. Notes: $* * *, * *, *, \dagger$ refer to $0.1 \%, 1 \%, 5 \%$, and $10 \%$ levels of significance, respectively. Figures in parenthesis are t-statistics. Sample: 2000-2013. Periods included: 14. Cross-sections included: 50. Total panel (balanced) observations: 700. White cross-section standard errors \& covariance (d.f. corrected). For variable description, see

\section{Table 1.}

By extending the empirical research by means of quantile regressions (see Table 6), the results confirm the negative influence of Bindep on ECTR (all the estimated equations). Likewise, Bsize reveals a negative influence on ECTR (Eq 4 - Eq 8), but for quantiles over 0.3. Onward, we establish mixed associations between CEO_Hold and ECTR: positive (for quantiles between 0.3 and 0.5 ) and negative (at the 0.9 quantile or the 90th percentile). CEO_Tenure positively influences ECTR for upper quantiles (0.8 and $0.9)$. All these results can be attributed to the fact that executive and independent members from the boards and CEO, all of them have different views, opinions and interests regarding the level of ECTR, as we mentioned in Section 2. 
Table 6: Quantile regressions of ECTR on corporate governance characteristics and firm-level controls

\begin{tabular}{|c|c|c|c|c|c|c|c|c|c|}
\hline & $\begin{array}{c}(1) \\
(\operatorname{tau}=0.1)\end{array}$ & $\begin{array}{c}(2) \\
(\operatorname{tau}=0.2)\end{array}$ & $\begin{array}{c}(3) \\
(\operatorname{tau}=0.3)\end{array}$ & $\begin{array}{c}(4) \\
(\operatorname{tau}=0.4)\end{array}$ & $\begin{array}{c}\text { (5) } \\
\text { (Median) }\end{array}$ & $\begin{array}{c}(6) \\
(\operatorname{tau}=0.6)\end{array}$ & $\begin{array}{c}(7) \\
(\operatorname{tau}=0.7)\end{array}$ & $\begin{array}{c}(8) \\
(\operatorname{tau}=0.8)\end{array}$ & $\begin{array}{c}(9) \\
(\operatorname{tau}=0.9)\end{array}$ \\
\hline C & $\begin{array}{l}0.066528 \\
(0.375935) \\
\end{array}$ & $\begin{array}{l}0.275689^{* * *} \\
(3.647612) \\
\end{array}$ & $\begin{array}{l}0.28151^{* * *} \\
(6.155653)\end{array}$ & $\begin{array}{l}0.351005^{* * *} \\
(9.119786)\end{array}$ & $\begin{array}{l}0.401985^{* * *} \\
(11.68985) \\
\end{array}$ & $\begin{array}{l}0.405778 \text { *** } \\
(11.85843) \\
\end{array}$ & $\begin{array}{l}0.433383^{* * *} \\
(15.56895) \\
\end{array}$ & $\begin{array}{l}0.44391^{* * *} \\
(17.07632)\end{array}$ & $\begin{array}{l}0.449031^{* * *} \\
(14.66927)\end{array}$ \\
\hline BIndep & $\begin{array}{c}-0.073812^{\dagger} \\
(-1.666869)\end{array}$ & $\begin{array}{l}-0.091075^{* * *} \\
(-3.429082) \\
\end{array}$ & $\begin{array}{l}-0.09593^{* * *} \\
(-4.109642)\end{array}$ & $\begin{array}{l}-0.114081^{* * *} \\
(-5.384732)\end{array}$ & $\begin{array}{c}-0.100812^{* * *} \\
(-4.18715)\end{array}$ & $\begin{array}{c}-0.081146{ }^{* *} \\
(-3.11463)\end{array}$ & $\begin{array}{c}-0.058332^{* *} \\
(-2.928936)\end{array}$ & $\begin{array}{l}-0.057615^{* *} \\
(-3.311064)\end{array}$ & $\begin{array}{l}-0.053964 \\
(-2.948644)\end{array}$ \\
\hline BSize & $\begin{array}{c}-0.007134 \\
(-0.101425) \\
\end{array}$ & $\begin{array}{c}-0.037581 \\
(-1.483273) \\
\end{array}$ & $\begin{array}{c}-0.028911 \\
(-1.506236) \\
\end{array}$ & $\begin{array}{l}-0.047476^{* *} \\
(-2.706478)\end{array}$ & $\begin{array}{c}-0.057304^{* * *} \\
(-3.553233) \\
\end{array}$ & $\begin{array}{c}-0.029313^{*} \\
(-2.074104) \\
\end{array}$ & $\begin{array}{l}-0.028798^{*} \\
(-2.389044) \\
\end{array}$ & $\begin{array}{c}-0.024133^{*} \\
(-1.985662) \\
\end{array}$ & $\begin{array}{c}-0.016617 \\
(-1.035127)\end{array}$ \\
\hline CEO_Hold & $\begin{array}{c}0.008896 \\
(0.070385)\end{array}$ & $\begin{array}{c}-0.096234 \\
(-0.581961) \\
\end{array}$ & $\begin{array}{c}0.017537^{* * *} \\
(3.963932)\end{array}$ & $\begin{array}{l}0.015013^{* *} \\
(2.912447)\end{array}$ & $\begin{array}{c}0.010373^{+} \\
(1.902574)\end{array}$ & $\begin{array}{c}0.005493 \\
(0.991757) \\
\end{array}$ & $\begin{array}{c}-0.000399 \\
(-0.080586)\end{array}$ & $\begin{array}{c}-0.003924 \\
(-0.971794) \\
\end{array}$ & $\begin{array}{l}-0.008204^{* *} \\
(-2.632252)\end{array}$ \\
\hline CEO_Tenure & $\begin{array}{c}-0.004395 \\
(-1.540072)\end{array}$ & $\begin{array}{c}-0.002735 \\
(-0.638613) \\
\end{array}$ & $\begin{array}{c}-0.002045 \\
(-0.921798)\end{array}$ & $\begin{array}{c}0.000449 \\
(0.213169) \\
\end{array}$ & $\begin{array}{c}0.001768 \\
(1.359415)\end{array}$ & $\begin{array}{c}0.001447 \\
(1.204848)\end{array}$ & $\begin{array}{l}0.001069 \\
(1.22411) \\
\end{array}$ & $\begin{array}{c}0.001554^{*} \\
(2.039934)\end{array}$ & $\begin{array}{c}0.002026^{*} \\
(2.289913)\end{array}$ \\
\hline FSize & $\begin{array}{c}0.003516 \\
(0.556626)\end{array}$ & $\begin{array}{c}0.001094 \\
(0.357521)\end{array}$ & $\begin{array}{c}0.000626 \\
(0.347368)\end{array}$ & $\begin{array}{c}0.001195 \\
(0.680176)\end{array}$ & $\begin{array}{c}0.001794 \\
(0.877518)\end{array}$ & $\begin{array}{c}-0.001408 \\
(-0.739452)\end{array}$ & $\begin{array}{l}-0.0000884 \\
(-0.054747)\end{array}$ & $\begin{array}{c}0.000096 \\
(0.064242)\end{array}$ & $\begin{array}{c}0.000214 \\
(0.143924)\end{array}$ \\
\hline ROA & $\begin{array}{l}0.284574 \\
(4.717771)\end{array}$ & $\begin{array}{c}0.121313^{+} \\
(1.695604)\end{array}$ & $\begin{array}{c}0.154299^{* * *} \\
(3.9376)\end{array}$ & $\begin{array}{c}0.093797^{*} \\
(2.299847)\end{array}$ & $\begin{array}{c}0.046076 \\
(1.036337)\end{array}$ & $\begin{array}{c}0.008837 \\
(0.186501)\end{array}$ & $\begin{array}{c}-0.069506 \\
(-1.505615)\end{array}$ & $\begin{array}{c}-0.069716^{\dagger} \\
(-1.799627)\end{array}$ & $\begin{array}{c}-0.086888^{*} \\
(-2.42992)\end{array}$ \\
\hline Debt/Equity & $\begin{array}{c}-0.027251^{*} \\
(-2.482934)\end{array}$ & $\begin{array}{c}-0.025674^{* * *} \\
(-4.80912)\end{array}$ & $\begin{array}{l}-0.02175^{* * *} \\
(-4.496545)\end{array}$ & $\begin{array}{l}-0.024191^{* * *} \\
(-5.379534)\end{array}$ & $\begin{array}{l}-0.024798^{* * *} \\
(-4.738151)\end{array}$ & $\begin{array}{c}-0.023522^{* * *} \\
(-3.404866)\end{array}$ & $\begin{array}{c}-0.016075^{* * *} \\
(-3.386182)\end{array}$ & $\begin{array}{l}-0.017241^{* * *} \\
(-4.322949)\end{array}$ & $\begin{array}{l}-0.023207^{* * *} \\
(-7.230052)\end{array}$ \\
\hline Debt/Assets & $\begin{array}{c}0.125166^{*} \\
(2.524784)\end{array}$ & $\begin{array}{l}0.126668^{* *} \\
(3.287706)\end{array}$ & $\begin{array}{l}0.109733^{* * *} \\
(3.989836)\end{array}$ & $\begin{array}{l}0.118305^{* * *} \\
(4.864765)\end{array}$ & $\begin{array}{l}0.100253^{* * *} \\
(3.520345)\end{array}$ & $\begin{array}{c}0.079697^{*} \\
(2.101797)\end{array}$ & $\begin{array}{c}0.027051 \\
(0.900147)\end{array}$ & $\begin{array}{c}0.011851 \\
(0.447197)\end{array}$ & $\begin{array}{c}0.015766 \\
(0.684225)\end{array}$ \\
\hline Pseudo R-sq & 0.066178 & 0.066030 & 0.064088 & 0.054352 & 0.045637 & 0.043422 & 0.049494 & 0.054637 & 0.064143 \\
\hline Adj R-sq & 0.055367 & 0.055217 & 0.053253 & 0.043404 & 0.034588 & 0.032348 & 0.038489 & 0.043692 & 0.053308 \\
\hline
\end{tabular}

Source: Author's computations. Notes: ${ }^{* *}, * *, *, \dagger$ refer to $0.1 \%, 1 \%, 5 \%$, and $10 \%$ levels of significance, respectively. Figures in parenthesis are t-statistics. Sample: 2000-2013. Included observations: 700. Huber Sandwich Standard Errors \& Covariance. Sparsity method: Kernel (Epanechnikov) using residuals. For variable description, see 
Table 1.

Radu Alin Păunescu, Georgeta Vintilă and Ștefan Cristian Gherghina (2016), Journal of Financial Studies \& Research, DOI: 10.5171/2016.857506 
By employing robustness checks via panel EGLS, GLM, and panel GMM (see Table 7), the negative influence of board independence (all the estimated models) and board size (Eq 2) is strengthened. However, the lack of influence related to CEO_Hold is emphasized. In addition, the influence of CEO_Tenure is mixed: positive (Eq 1) and negative (Eq 3 and
Eq 4). Contrary to Gupta and Newberry (1997) results, ROA had a negative sign for GMM estimation method. This fact shows that managers can use the financial performance to reduce ECTR, as a political power and in the interest of the company and shareholders.

Table 7: Robustness checks

\begin{tabular}{|c|c|c|c|c|}
\hline & $\begin{array}{c}\text { (1) } \\
\text { Panel EGLS }\end{array}$ & $\begin{array}{c}\text { (2) } \\
\text { GLM }\end{array}$ & $\begin{array}{c}\text { (3) } \\
\text { Panel GMM }\end{array}$ & $\begin{array}{c}\text { (4) } \\
\text { Panel GMM }\end{array}$ \\
\hline C & $\begin{array}{c}0.650137^{* * *} \\
(10.09393)\end{array}$ & $\begin{array}{l}0.335856^{* * *} \\
(9.682227)\end{array}$ & & \\
\hline $\operatorname{ECTR~(-1)~}$ & & & $\begin{array}{l}0.051334^{* * *} \\
(5.559802)\end{array}$ & $\begin{array}{l}0.098748 * * \\
(4.519264)\end{array}$ \\
\hline $\operatorname{ECTR~(-2)~}$ & & & $\begin{array}{l}-0.081641^{* * *} \\
(-10.11675)\end{array}$ & $\begin{array}{c}-0.061411^{\dagger} \\
(-1.903375)\end{array}$ \\
\hline ECTR (-3) & & & & $\begin{array}{c}0.00309 \\
(0.432081)\end{array}$ \\
\hline BIndep & $\begin{array}{c}-0.038386^{* * *} \\
(-5.7482) \\
\end{array}$ & $\begin{array}{l}-0.08602^{* * *} \\
(-4.313684)\end{array}$ & $\begin{array}{c}-0.0149866^{* * *} \\
(-3.67599)\end{array}$ & $\begin{array}{l}-0.0217366^{* *} \\
(-2.790915) \\
\end{array}$ \\
\hline BSize & $\begin{array}{l}-0.011604 \\
(-0.71747)\end{array}$ & $\begin{array}{c}-0.033012^{*} \\
(-2.086933)\end{array}$ & $\begin{array}{c}-0.025857 \\
(-0.491113)\end{array}$ & $\begin{array}{c}-0.022595 \\
(-0.202436) \\
\end{array}$ \\
\hline CEO_Hold & $\begin{array}{c}-0.00067 \\
(-0.619909) \\
\end{array}$ & $\begin{array}{c}-0.001964 \\
(-0.134949) \\
\end{array}$ & $\begin{array}{c}-0.028311 \\
(-1.227271) \\
\end{array}$ & $\begin{array}{l}0.009345 \\
(0.14737) \\
\end{array}$ \\
\hline CEO_Tenure & $\begin{array}{c}0.001557^{\dagger} \\
(1.686683)\end{array}$ & $\begin{array}{c}0.000415 \\
(0.414804)\end{array}$ & $\begin{array}{l}-0.00977^{* * *} \\
(-5.003908)\end{array}$ & $\begin{array}{c}-0.009972^{* * *} \\
(-4.859088)\end{array}$ \\
\hline FSize & $\begin{array}{c}-0.021461^{* * *} \\
(-7.705145)\end{array}$ & $\begin{array}{c}0.002533^{\dagger} \\
(1.655766)\end{array}$ & $\begin{array}{c}-0.000755 \\
(-0.126371)\end{array}$ & $\begin{array}{c}0.01567 \\
(0.58471)\end{array}$ \\
\hline ROA & $\begin{array}{c}0.023917 \\
(1.185321)\end{array}$ & $\begin{array}{l}0.002866 \\
(0.04711) \\
\end{array}$ & $\begin{array}{l}-0.198435^{* * *} \\
(-7.162111)\end{array}$ & $\begin{array}{c}-0.129719 \\
(-1.546311) \\
\end{array}$ \\
\hline Debt/Equity & $\begin{array}{c}-0.012953^{\dagger} \\
(-1.868962)\end{array}$ & $\begin{array}{c}-0.019907^{* * *} \\
(-4.299573)\end{array}$ & $\begin{array}{l}-0.012865^{*} \\
(-2.042611)\end{array}$ & $\begin{array}{c}-0.011565 \\
(-1.437264)\end{array}$ \\
\hline Debt/Assets & $\begin{array}{c}-0.014362 \\
(-0.712326)\end{array}$ & $\begin{array}{c}0.055254^{*} \\
(2.230963) \\
\end{array}$ & $\begin{array}{c}-0.039639 \\
(-1.242088) \\
\end{array}$ & $\begin{array}{c}-0.026874 \\
(-0.847926) \\
\end{array}$ \\
\hline F-value & $24.47646^{* * *}$ & & & \\
\hline $\operatorname{Pr}>F$ & 0.000000 & & & \\
\hline R-sq & 0.684855 & & & \\
\hline Adj R-sq & 0.656875 & & & \\
\hline J-stat & & & 41.99032 & 40.14358 \\
\hline
\end{tabular}

Source: Author's computations. Notes: ${ }^{* * *}, * *, *, \dagger$ refer to $0.1 \%, 1 \%, 5 \%$, and $10 \%$ levels of significance, respectively. Figures in parenthesis are t-statistics. Sample: 2000-2013. For variable description, see 
Table 1.

Table 8 reports the output of Granger causality examination. We find, only for the first lag, that board independence Granger causes ECTR, even if the reverse causality is not valid. This fact is associated with the reluctance of the independent members about tax avoidance.

Table 8: Pair wise Granger Causality Tests

\begin{tabular}{|c|c|c|c|c|c|c|}
\hline \multirow[b]{2}{*}{ Null Hypothesis } & \multicolumn{2}{|r|}{ Lag 1} & \multicolumn{2}{|r|}{ Lag 2} & \multicolumn{2}{|r|}{ Lag 3} \\
\hline & Obs & $\begin{array}{c}\text { F-Statistic } \\
\text { (Prob.) }\end{array}$ & Obs & $\begin{array}{c}\text { F-Statistic } \\
\text { (Prob.) }\end{array}$ & Obs & $\begin{array}{c}\text { F-Statistic } \\
\text { (Prob.) }\end{array}$ \\
\hline BINDEP does not Granger Cause ECTR & \multirow{2}{*}{650} & $\begin{array}{l}5.04025 \\
(0.0251)\end{array}$ & \multirow{2}{*}{600} & $\begin{array}{l}1.67727 \\
(0.1878) \\
\end{array}$ & \multirow{2}{*}{550} & $\begin{array}{l}1.11813 \\
(0.3411) \\
\end{array}$ \\
\hline ECTR does not Granger Cause BINDEP & & $\begin{array}{l}0.23711 \\
(0.6265) \\
\end{array}$ & & $\begin{array}{l}2.28122 \\
(0.1031) \\
\end{array}$ & & $\begin{array}{c}1.51312 \\
(0.2101) \\
\end{array}$ \\
\hline BSIZE does not Granger Cause ECTR & \multirow{2}{*}{650} & $\begin{array}{l}0.86071 \\
(0.3539) \\
\end{array}$ & \multirow{2}{*}{600} & $\begin{array}{l}0.21603 \\
(0.8058) \\
\end{array}$ & \multirow{2}{*}{550} & $\begin{array}{l}0.30959 \\
(0.8185) \\
\end{array}$ \\
\hline ECTR does not Granger Cause BSIZE & & $\begin{array}{l}0.31656 \\
(0.5739) \\
\end{array}$ & & $\begin{array}{l}0.39977 \\
(0.6707) \\
\end{array}$ & & $\begin{array}{l}0.88870 \\
(0.4467) \\
\end{array}$ \\
\hline CEO_HOLD does not Granger Cause ECTR & \multirow{2}{*}{650} & $\begin{array}{l}0.08060 \\
(0.7766) \\
\end{array}$ & \multirow{2}{*}{600} & $\begin{array}{l}0.00947 \\
(0.9906) \\
\end{array}$ & \multirow{2}{*}{550} & $\begin{array}{l}0.19101 \\
(0.9025) \\
\end{array}$ \\
\hline ECTR does not Granger Cause CEO_HOLD & & $\begin{array}{l}0.11494 \\
(0.7347) \\
\end{array}$ & & $\begin{array}{l}0.13314 \\
(0.8754) \\
\end{array}$ & & $\begin{array}{r}0.11233 \\
(0.9529) \\
\end{array}$ \\
\hline CEO_TENURE does not Granger Cause ECTR & \multirow{2}{*}{650} & $\begin{array}{l}0.22018 \\
(0.6391) \\
\end{array}$ & \multirow{2}{*}{600} & $\begin{array}{l}1.70847 \\
(0.1820)\end{array}$ & \multirow{2}{*}{550} & $\begin{array}{l}1.29218 \\
(0.2763)\end{array}$ \\
\hline ECTR does not Granger Cause CEO_TENURE & & $\begin{array}{l}6.67516 \\
(0.0100)\end{array}$ & & $\begin{array}{l}0.86698 \\
(0.4207)\end{array}$ & & $\begin{array}{l}0.65974 \\
(0.5771)\end{array}$ \\
\hline
\end{tabular}

Source: Author's computations. For variable description, see 
Table 1.

In addition, for the first lag, ECTR Granger causes CEO tenure. Economically, this can be explained by the fact that only the experienced CEOs can juggle it with the tax system breaches and regulation, so that, taxation's harshness has an influence when a company employs a CEO, according to his tenure. For the rest of variables and lags, the causality relationships are not statistically significant.

\section{Concluding Remarks}

This paper examines the link between corporate governance characteristics and effective corporate tax rate. We extend the empirical research by estimating panel least squares regressions and quantile regressions. From the perspective of board characteristics, the results provide support for a negative influence of board independence on effective corporate tax rate opposite Ribeiro et al. (2015), but similar to Armstrong et al. (2015) for high levels of tax avoidance. Also, we ascertain a negative influence of board size on effective corporate tax rate contrary to Ribeiro et al. (2015), due to issues related to communication and coordination. As regards CEO characteristics, we find mixed results between CEO ownership and corporate taxation by means of quantile regression. Also, CEO tenure documents opposed results, namely negative influence when estimating panel least squares regressions (cross-section fixed) and positive for upper quantiles regressions. The robustness checks confirm the negative influence of board characteristics on effective corporate tax rate and support the mixed influence of CEO tenure. Likewise, the Granger (1969) approach emphasizes that board independence Granger causes corporate taxation. All these findings can be explained by the influence of informational asymmetry and agency problems, but the true puppeteer behind the scene is the human nature which acts in the benefit of its owner: managers, directors, board members and shareholders.

\section{References}

1. Armstrong, C., Blouin, J. L., Jagolinzer, A. D., Larcker, D. F. (2015). Corporate Governance, Incentives, and Tax Avoidance. Journal of Accounting and Economics, 60(1): 1-17.

http://dx.doi.org/10.1016/j.jacceco.2015.02. 003

2. Badertscher, B. A., Katz, S. P., Rego, S. O. (2013). The separation of ownership and control and corporate tax avoidance. Journal of Accounting and Economics, 56(2-3): 228250.

http://dx.doi.org/10.1016/j.jacceco.2013.08. 005 
3. Bauman, C., Schadewald, M. (2001). Impact of foreign operations on reported effective tax rates: interplay of foreign taxes, US taxes and US GAAP. Journal of International Accounting, Auditing \& Taxation, 10(2): 177-196. http://dx.doi.org/10.1016/S10619518(01)00043-X

4. Bhagat, S., Bolton, B. (2008). Corporate governance and firm performance. Journal of Corporate Finance, 14(3), 257-273. http://dx.doi.org/10.1016/j.jcorpfin.2008.03 .006

5. Blaylock, B. S. (2011). Do Managers Extract Economically Significant Rents Through Tax Aggressive Transactions? Working Paper. Oklahoma State University. (August 30, 2011). http://dx.doi.org/10.2139/ssrn.1911265

6. Chen, S., Chen, X., Cheng, Q., Shevlin, T. (2010). Are family firms more tax aggressive than non-family firms? Journal of Financial Economics, $\quad$ 95(1): 41-61. http://dx.doi.org/10.1016/j.jfineco.2009.02. 003

7. Desai, M. A., Dharmapala, D. (2006). Corporate tax avoidance and high powered incentives. Journal of Financial Economics, 79(1):

145-179.

http://dx.doi.org/10.1016/j.jfineco.2005.02. 002

8. Devereux, M. P., Griffith, R. (1999). The Taxation of Discrete Investment Choices. Revision 2. The Institute For Fiscal Studies. Working Paper Series No. W98/16.

9. Dyreng, S. D., Hanlon M., Maydew, E. L. (2010). The Effects of Executives on Corporate Tax Avoidance. The Accounting Review, 85(4): 1163-1189. http://dx.doi.org/10.2308/accr.2010.85.4.11 63

10.Erkens, D. H., Hung, M., Matos, P. (2012). Corporate governance in the 2007-2008 financial crisis: Evidence from financial institutions worldwide. Journal of Corporate Finance, $\quad$ 18(2): 389-411. http://dx.doi.org/10.1016/j.jcorpfin.2012.01 .005

11.Florackis, C. (2008). Agency costs and corporate governance mechanisms: evidence for UK firms. International Journal of Managerial Finance, 4(1): 37-59. http://dx.doi.org/10.1108/1743913081083 7375

12.Fraile, I. A., Fradejas, N. A. (2014). Ownership structure and board composition in a high ownership concentration context. European Management Journal, 32(4): 646657.

http://dx.doi.org/10.1016/j.emj.2013.10.003

13.Gallemore, J., Maydew, E. L., Thornock, J. R. (2012). The reputational costs of tax avoidance and the under-sheltering puzzle. Working Paper. University of North Carolina http://papers.ssrn.com/sol3/papers.cfm?abs tract_id=1986226

14.Granger, C. W. J. (1969). Investigating Causal Relations by Econometric Models and Cross-spectral Methods. Econometrica, 37(3): 424-438.

http://dx.doi.org/10.2307/1912791

15.Griffith, R., Miller, H., O'Connell, M. (2014). Ownership of intellectual property and corporate taxation. Journal of Public Economics, 112(1): 12-23. http://dx.doi.org/10.1016/j.jpubeco.2014.01 .009

16.Gupta, S., Newberry, K. (1997). Determinants of the Variability in Corporate Effective Tax Rates: Evidence from Longitudinal Data. Journal of International Accounting and Public Policy, 16(1): 1-34. http://dx.doi.org/10.1016/S02784254(96)00055-5

17.Hanlon, M., Heitzman, S. (2010). A review of tax research. Journal of Accounting and Economics, $\quad$ 50(2-3): $\quad$ 127-178. 
http://dx.doi.org/10.1016/j.jacceco.2010.09. 002

18.Jacob, J. (1996). Taxes and Transfer Pricing: Income Shifting and the Volume of Intrafirm Transfers. Journal of Accounting Research, 34(2): 301-312. http://dx.doi.org/10.2307/2491504

19.Kahneman, D., Tversky, A. (1979). Prospect Theory: An Analysis of Decision under Risk. Econometrica, 47(2): 263-292. http://dx.doi.org/10.2307/1914185

20.Kahneman, D., Tversky, A. (1986). Rational Choice and the Framing of Decisions. The Journal of Business, 59(4): S251-S278.

21.Lasfer, M. A. (1995). Agency Costs, Taxes and Debt: The UK Evidence. European Financial Management, 1(3): 265285. http://dx.doi.org/10.1111/j.1468036X.1995.tb00020.x

22.Lee, N., Swenson, C. (2012). Are Multinational Corporate Tax Rules as Important as Tax Rates? The International Journal of Accounting, 47(2): 155-167. http://dx.doi.org/10.1016/j.intacc.2012.03.0 01

23.Lisowsky, P. (2010) Seeking Shelter: Empirically Modeling Tax Shelters Using Financial Statement Information. The Accounting Review, 85(5): 1693-1720. http://dx.doi.org/10.2308/accr.2010.85.5.16 93

24.MacAvoy, P., Millstein I. M. (1999). The Active Board of Directors and Its Effect on the Performance of the Large Publicly Traded Corporation. Journal of Applied Corporate Finance 11(4): 8-20. http://dx.doi.org/10.1111/j.17456622.1999.tb00510.x

25.Metrick, A., Ishii, J. (2002). Firm-level corporate governance. Paper presented at Global Corporate Governance Forum Research Network Meeting, Washington, D.C.
26.Mills, L., Erickson, M. M., Maydew, E. L. (1998). Investments in Tax Planning. The Journal of the American Taxation Association, 20(1): 1-20.

27.Minnick, K., Noga, T. (2010). Do corporate governance characteristics influence tax management? Journal of Corporate Finance, 16(5): 703-718. http://dx.doi.org/10.1016/j.jcorpfin.2010.08 .005

28. Nicodème G., Barrios S., Sanchez F., Antonio J. (2014). Effective Corporate Taxation, Tax Incidence and Tax Reforms: Evidence from OECD Countries. CESifo Working Paper Series No. 5017. http://ssrn.com/abstract=2518381

29.Noor, R.M., Fadzillah, N. S. M., Mastuki, Nor'Azam (2010). Tax planning and corporate effective tax rates. 2010 International Conference on Science and Social Research, Kuala Lumpur, Malaysia, ISBN: 978-1-4244-8987-9. http://dx.doi.org/10.1109/CSSR.2010.57737 26

30.Omer, T., Molloy, K., Ziebart, D. (1993). An Investigation of the Firm Size - Effective Tax Rate Relation in the 1980s. Journal of Accounting, Auditing, and Finance, 8(2): 167182.

31.Porcano, T. M. (1986). Corporate Tax Rates: Progressive, Proportional, or Regressive. The Journal of the American Taxation Association, 7(2): 17-31.

32.Rego, S. O., Wilson, R. (2012). Equity risk incentives and corporate tax aggressiveness. Journal of Accounting Research, 50(3): 775810. http://dx.doi.org/10.1111/j.1475679X.2012.00438.x

33.Ribeiro, A., Cerqueira, A., Brandão, E. (2015). The Determinants of Effective Tax Rates: Firms' Characteristics and Corporate Governance. FEP Working Papers 567, ISSN: 0870-8541, School of Economics and Management, University of Porto. 
34.Richardson, G., Lanis, R., (2007). Determinants of the variability in corporate effective tax rates and tax reform: Evidence from Australia. Journal of Accounting and Public Policy, 26(6): 689-704. http://dx.doi.org/10.1016/j.jaccpubpol.2007 .10 .003

35.Robinson, J. R., Xue, Y., Zhang, M. H. (2012). Tax planning and financial expertise in the audit committee. Working Paper. University of Texas at Austin. http://dx.doi.org/10.2139/ssrn.2146003

36.Stickney, C. P., McGee, V. E. (1982). Effective Corporate Tax Rates: The Effect of Size, Capital Intensity, Leverage, and Other Factors. Journal of Accounting and Public Policy, 1(2): 125-152.

http://dx.doi.org/10.1016/S0278-

4254(82)80004-5

37.Vintilă, G., Păunescu, R. A (2015). Effective Corporate Tax Rate for US Companies in the Context of CEO Remuneration. Proceedings of the 26th International Business Information Management Association (IBIMA), Madrid, Spain, ISBN: 978-0-9860419-5-2.

38.Vintilă G., Păunescu R. A., Gherghina Ş. C. (2015). Does Corporate Governance Influences Corporate Financial Performance? Empirical Evidences for the Companies Listed on US Markets, International Business Research, 8(8): 27-49. http://dx.doi.org/10.5539/ibr.v8n8p27

39.Wahab, N. S. A., Holland, K. (2012). Tax Planning, Corporate Governance and Equity Value. British Accounting Review, 44(2): 111124.

http://dx.doi.org/10.1016/j.bar.2012.03.005

40.Watson, L. (2011) Social Influences on Aggressive Accounting: The Impact of Corporate Social Responsibility on Tax Aggressiveness. Paper presented at the American Accounting Association Annual Meeting, Denver, Colorado.
41.Wilson, R. J. (2009). An Examination of Corporate Tax Shelter Participants. The Accounting Review, 84(3): 969-999. http://dx.doi.org/10.2308/accr.2009.84.3.96 9

42.Yermack, D. (1996). Higher valuation of companies with a small board of directors. Journal of Financial Economics, 40(2): 185212. http://dx.doi.org/10.1016/0304405X(95)00844-5

43.Zimmerman, J. L. (1983). Taxes and firm size. Journal of Accountmg and Economics, 5: 119-149. http://dx.doi.org/10.1016/01654101(83)90008-3 